\title{
Az első hazai direkt akusztikus középfül-implantáció
}

\author{
Uzsaly János dr. - Gerlinger Imre dr. - Bodzai Gréta dr. \\ Kovács Márton dr. - Bakó Péter dr.
}

Pécsi Tudományegyetem, Általános Orvostudományi Kar, Klinikai Központ, Fül-Orr-Gégészeti és Fej-Nyaksebészeti Klinika, Pécs

\begin{abstract}
A hallásjavító implantátumok térnyerésével szinte bármely súlyosságú halláscsökkenés hatékonyan rehabilitálható. Magyarországon először a Pécsi Tudományegyetem Klinikai Központjának Fül-Orr-Gégészeti és Fej-Nyaksebészeti Klinikáján került sor Codacs ${ }^{\mathrm{TM}}$ (Cochlear's direct acoustic cochlear stimulator; Cochlear, Sydney, Ausztrália) implantációjára. Ez az implantátum egy, a középfülbe helyezhető elektromechanikus elven múködő hallásjavító eszköz, melyet súlyos fokú, siketséggel határos, kevert típusú, kétoldali halláscsökkenés esetén ajánlhatunk fel betegeinknek. Esetünkben kétoldali előrehaladott otosclerosisban szenvedő, 67 éves férfi betegünk részesült Codacs ${ }^{\mathrm{TM}}$-implantációban, mellyel páciensünk posztoperatív hallásküszöbe és beszédértése nagymértékben javult.

Orv Hetil. 2020; 161(24): 1015-1019.
\end{abstract}

Kulcsszavak: Codacs ${ }^{\mathrm{TM}}$, kétoldali kevert halláscsökkenés, középfül-implantátum, otosclerosis

\section{The first direct acoustic middle-ear implantation in Hungary}

Due to the remarkable development in the field of hearing implantation, almost all kinds of hearing loss can be successfully rehabilitated. The first Hungarian Codacs $^{\mathrm{TM}}$ (Cochlear's direct acoustic cochlear stimulator; Cochlear, Sydney, Australia) implantation was performed at the Department of Otorhinolaryngology and Head-Neck Surgery, Clinical Centre, University of Pécs. This electromechanical middle-ear implant can be offered for patients with bilateral, severe to profound, mixed-type hearing loss. In our case, a 67-year-old male patient with bilateral advanced otosclerosis was implanted, which led to significant improvement of the hearing threshold and speech reception.

Keywords: Codacs ${ }^{\mathrm{TM}}$, bilateral mixed hearing loss, middle-ear implant, otosclerosis

Uzsaly J, Gerlinger I, Bodzai G, Kovács M, Bakó P. [The first direct acoustic middle-ear implantation in Hungary]. Orv Hetil. 2020; 161(24): 1015-1019.

(Beérkezett: 2020. január 5.; elfogadva: 2020. március 10.)

\begin{abstract}
Rövidítések
Codacs $^{\mathrm{TM}}=$ (Cochlear's direct acoustic cochlear stimulator $)$ a Cochlear cég (Sydney, Ausztrália) direkt akusztikus cochleastimulátorának márkaneve; DACS $=$ (direct acoustic cochlear stimulator) direkt akusztikus cochleastimulátor; HRCT = (high-resolution computed tomography) nagy felbontású számítógépes tomográfia; KTP $=$ (potassium titanyl phosphate) kálium-titanil-foszfát; MET = middle ear transducer; SZTE = Szegedi Tudományegyetem
\end{abstract}

A hallórendszer károsodásának helye szerint többféle típusú halláscsökkenés jöhet létre. Amennyiben izoláltan a hangvezető rendszert (külső hallójárat, dobhártya, hallócsontláncolat) éri valamilyen noxa, akkor vezetéses halláscsökkenés alakul ki, míg ha a jelfogó, feldolgozóstruktúrák betegszenek meg, akkor sensorineuralis (percepciós) halláscsökkenésről beszélünk. A sensorineuralis halláscsökkenést a laesio helye szerint két további csoportra oszthatjuk, belsőfül-eredetü, ún. cochlearis és attól centrálisan létrejövő retrocochlearis halláscsökkenésre. A vezetéses és a sensorineuralis halláskárosodás kombinációja esetén kevert típusú halláscsökkenéssel állunk szemben.

Az otosclerosis a humán oticus capsula és a stapestalp primer megbetegedése, lokalizált csontdysplasiája, melynek etiopatogenezisét csak részben ismerjük. Kiterjedé- 
sétől függően okoz hallás-, illetve ritkán egyensúlyproblémát $[1,2]$. Az otoscleroticus plakkok a következő struktúrákon alakulnak ki a leggyakrabban: az ovális ablaktól anterior irányban a fissula ante fenestram területén, a kengyel talpán (80\%), a kerek ablakban (30\%), a pericochlearis régióban $(21 \%)$ és a belső hallójárat elülső falán (19\%) [3]. Amennyiben a fixált stapestalp uralja a képet, vezetéses halláscsökkenés van jelen, míg ha a csiga érintett, úgy idegi halláscsökkenés alakul ki. Több régió megbetegedésekor kevert típusú halláscsökkenést látunk. Mivel a legtöbb esetben a stapes fixáltsága okozza a panaszokat, mútéti megoldásként a leggyakrabban stapedotomia, illetve stapedectomia jön szóba [4]. A stapedectomia során a kengyel teljes talpa eltávolításra kerül, míg stapedotomia esetén a fixált talpon csak egy perforáció történik, és ide kerül be egy protézis. Ha idegi halláscsökkenés is jelen van, hallásjavító implantátumokra (Vibrant Soundbridge ${ }^{\mathrm{TM}}$ [Med-El, Innsbruck, Austria], Codacs ${ }^{\mathrm{TM}}$ [Cochlear, Sydney, Ausztrália], cochlearis implantátum) is szükség lehet. Hallásjavító készülékkel is történhet a hallásrehabilitáció. Vezetéses halláscsökkenés esetén ez fóképp akkor jön szóba, ha a beteg nem szeretne beavatkozást.

A hallásjavító implantátumok területén az elmúlt évtizedekben nagymértékű fejlődésnek lehettünk tanúi. A beültetés helye alapján beszélhetünk koponyacsontba, középfülbe, a belső fülbe és az agytörzs felszínére ültethető implantátumokról, melyekkel a legtöbb halláscsökkenés sikeresen rehabilitálható. Esetbemutatásunk kapcsán a középfülbe helyezhető Codacs $^{\mathrm{TM}}$ készülék al-

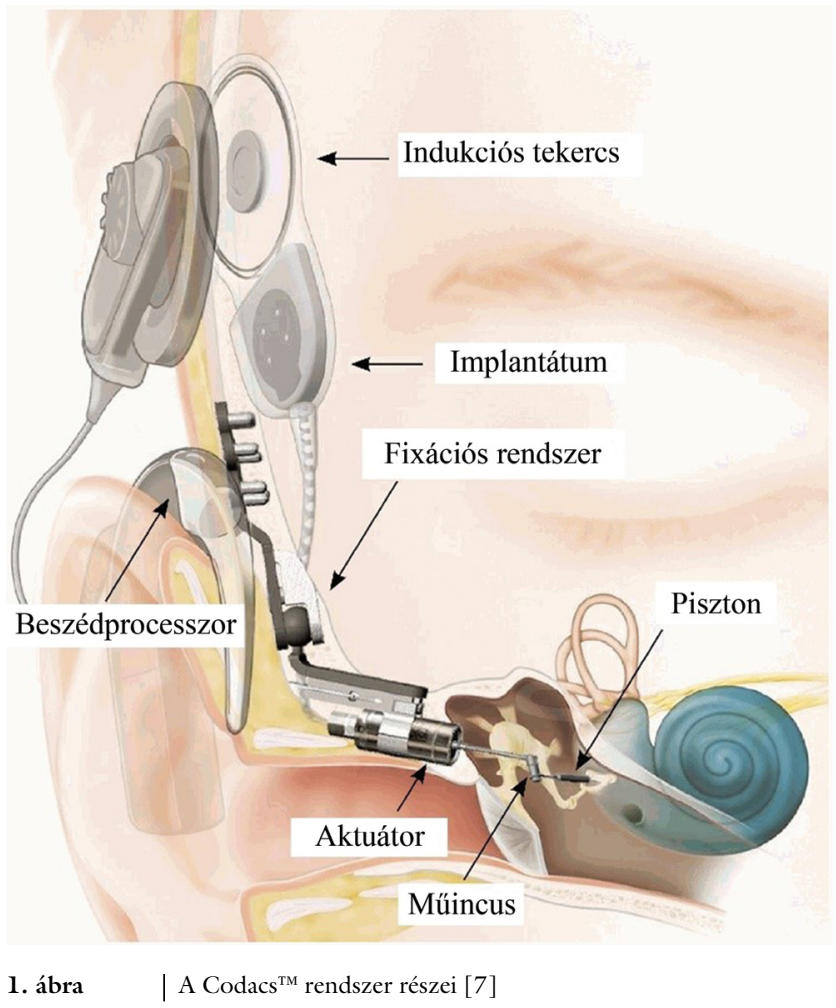

kalmazását mutatjuk be, amely egy elektromechanikus elven múködő hallásjavító eszköz (1. ábra) [5].

A középfül-implantátumokat múködési elvük alapján a következő három csoportba soroljuk: elektromágneses, elektromechanikus és a piezoelektromosság elvén múködő implantátumok. A Codacs ${ }^{\mathrm{TM}}$ (a MET és Carina implantátumokhoz hasonlóan, melyekben a SZTE SzentGyörgyi Albert Klinikai Központjának Fül-Orr-Gégészeti és Fej-Nyaksebészeti Klinikája szerzett jártasságot) elektromechanikus elven alapszik, ami azt jelenti, hogy a fülkagyló mögött elhelyezkedő beszédprocesszor az akusztikus jelet először digitális elektromos jellé alakítja, majd azt egy tekercsen keresztül az implantátum felé továbbítja. A szignált az implantátum analóg szignállá alakítja és az ún. aktuátorba küldi, az aktuátor pedig vibrációt keltve mechanikus úton hozza mozgásba a perilymphateret, aminek következtében a Corti-szerv múködésbe lép. Fixált stapes esetén stapedotomiát kell végezni, majd a stapedotomiás nyílásba piszton (protézis, mely a fixált kengyelt helyettesíti) kerül, melyet rögzítünk az aktuátorhoz kapcsolt múincushoz. Ezáltal a hallócsontláncolatot áthidalva az aktuátor-múincus-piszton tengelyen keresztül létrejön a mechanikus inger, mely hullámokat kelt a belső fülben. A középfül üregében az implantátum elmozdulását egy, a mastoid üregbe rögzülő fixációs rendszer akadályozza meg $[6,7]$.

\section{Esetismertetés}

Egy 67 éves férfi betegünk 2015 őszén jelentkezett Klinikánkon halláspanaszával. Elmondása szerint 35-40 éves kora óta a hallása mindkét oldalon, de fóként a bal oldalon folyamatosan romlott. A bal oldalon 1984-ben atticoantrotomia történt, a jobb oldalon pedig évek óta hallásjavító készüléket visel. Életminősége hosszú ideje rossz, családjától, barátaitól elszigetelten éli mindennapjait. Fülfájdalomra, fülfolyásra, szédülésre nem panaszkodott. A fizikális vizsgálat során a külső hallójáratok és a dobhártya statusában érdemi eltérést nem láttunk. A nervus facialis motoros múködése intakt volt, a pozitív Valsalva-manőver jó fülkürtfunkciót igazolt. A társalgó beszéd vizsgálatakor betegünk egyik oldalon sem tudta visszamondani a fülkagyló mellett (ad concham) elhangzott számokat. A hangvillavizsgálatok kapcsán, a Weberteszt során a hangot nem lateralizálta, és a Rinne-teszt mindkét oldalon negatívnak bizonyult. Szubjektív küszöbaudiológiai mérésekkel mindkét oldalon siketséggel határos, kevert típusú halláscsökkenést találtunk, tehát mind a légvezetés, mind a csontvezetés jelentős mértékben károsodott. Hallása a jobb oldalon rosszabbnak adódott: $500 \mathrm{~Hz}$-en már elérte a $100 \mathrm{~dB}$-t, és $1 \mathrm{kHz}$ felett a légvezetéses küszöb már nem is volt mérhető $(2 / A$ ábra). A jobb fülön a beszédküszöb-vizsgálaton, amelyen kétjegyű számokat kell a betegnek visszamondania, a legnagyobb intenzitás mellett sem volt pontos válasza. A mütétet megelőzően a beszédértés-vizsgálat során betegünk $100 \mathrm{~dB}$ hangintenzitás mellett sem tudott egy 

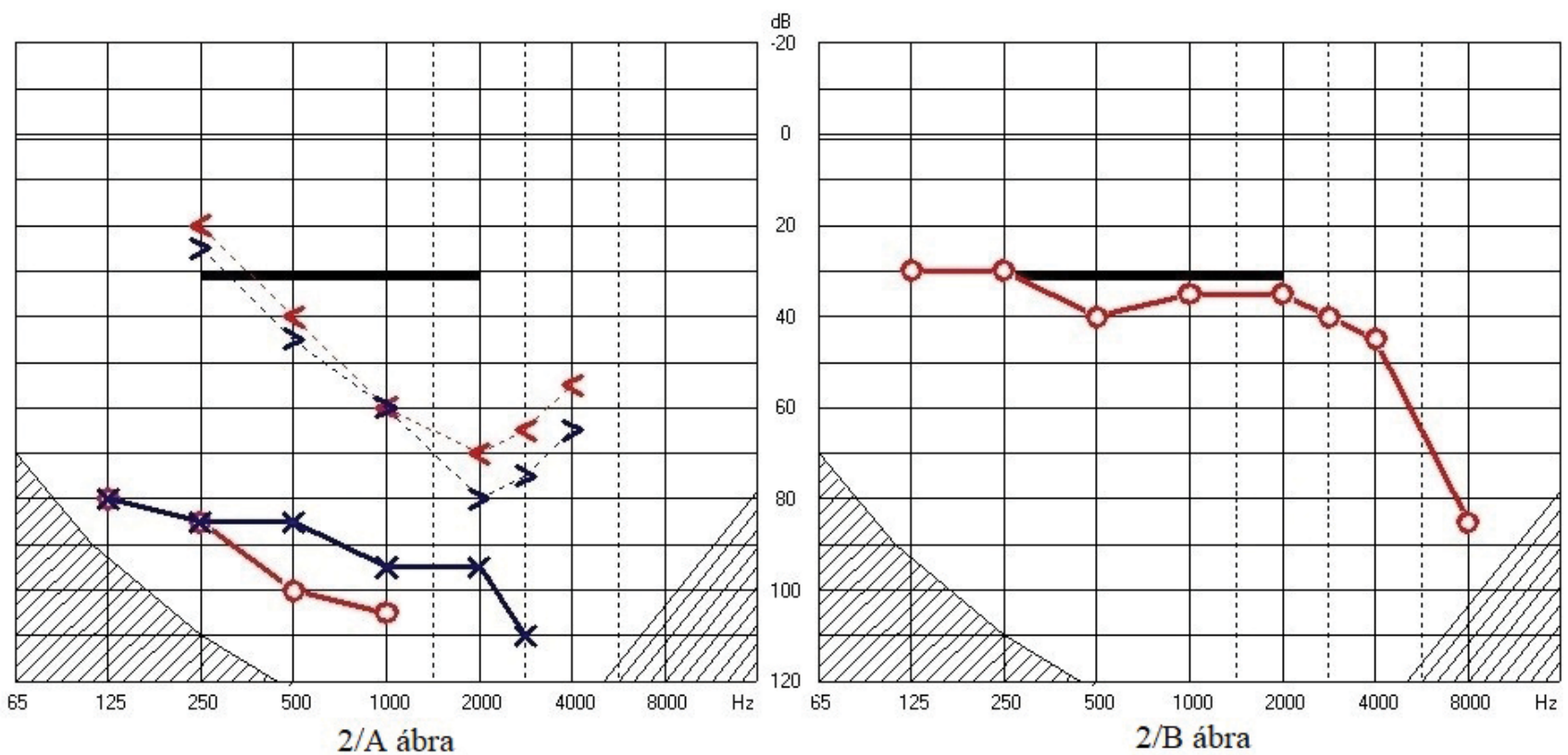

\begin{tabular}{l|l} 
2. ábra & $\begin{array}{l}\text { A preoperatív hallásküszöb (A) és a posztoperatív, bekapcsolt készülék mellett végzett, szabad hangteres vizsgálat (B) } \\
\text { (jelmagyarázat: <: jobb oldali csontvezetés; >: bal oldali csontvezetés; o: jobb oldali légvezetés; x: bal oldali légvezetés }\end{array}$
\end{tabular}

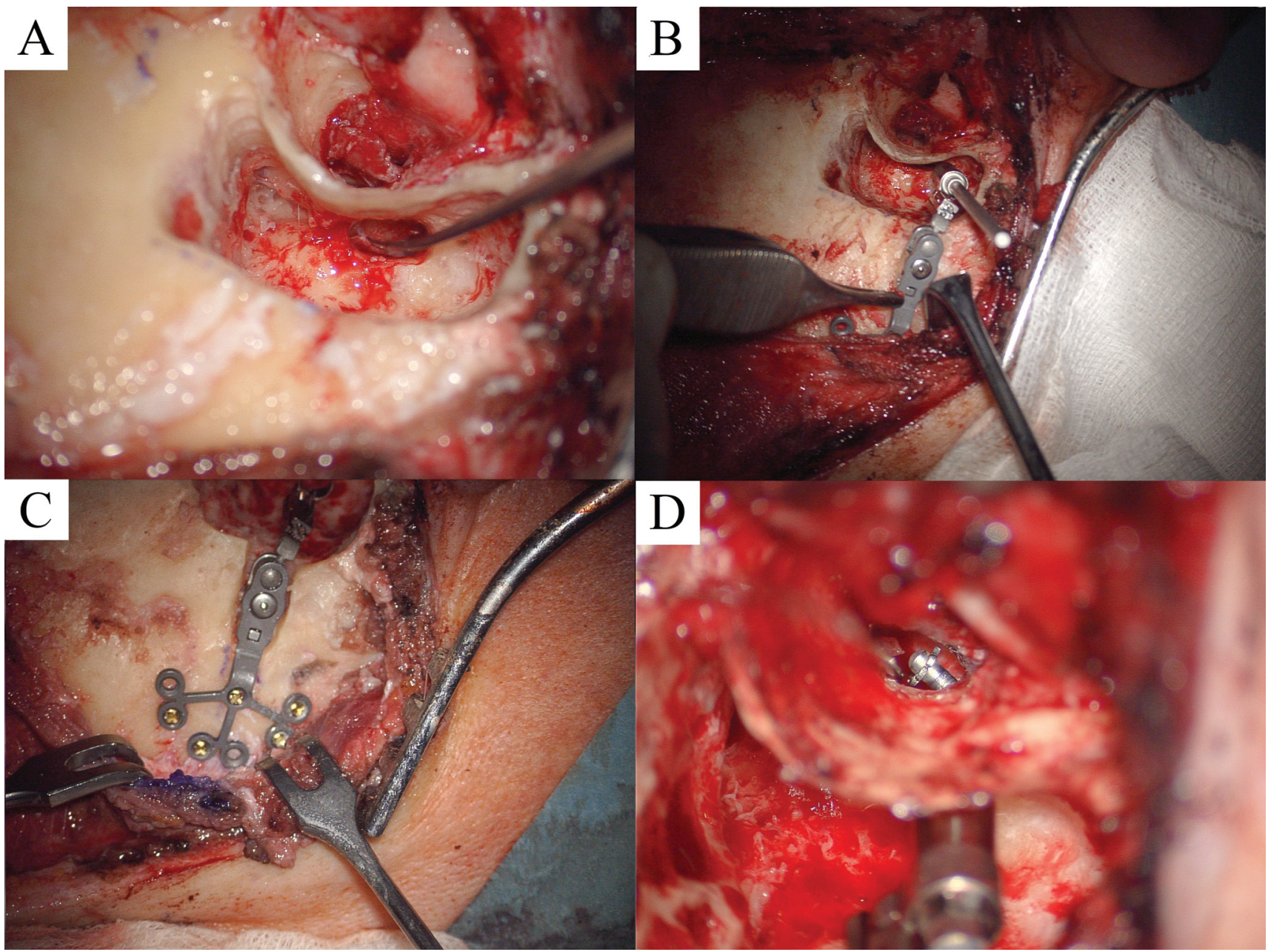

Intraoperatív képek. (A) Posterior tympanotomia: az eszköz a posterior tympanotomia helyét mutatja. A posterior tympanotomia során a dobüreget a mastoidealis sejtrendszer felól közelítjük meg; elölről a csontos hallójáratfal határolja, hátsó határa a nervus facialis mastoidealis szakasza. (B) A fixációs rendszer, az aktuátor és a múincus behelyezése. (C) A fixációs rendszer rögzítése. (D) A múincusra helyezett piszton 
szót sem visszamondani, tehát beszédértése a jobb oldalon 0\%-nak felelt meg. Sziklacsont-HRCT készült, melyen mindkét oldalon a temporalis csont felritkulása volt látható a csigák körül, azoktól anterior irányban, valamint a basalis kanyarulat mentén és a stapestalp körül is. Ezen radiológiai jelek, valamint az elvégzett fizikális és audiológiai vizsgálatok alapján a betegnél előrehaladott otosclerosist véleményeztünk, és felajánlottuk számára a jobb oldali Codacs ${ }^{\mathrm{TM}}$-beültetést.

A mütétre 2015. december 3-án került sor intratrachealis narcosisban. Endauralis metszésből felemeltük a dobhártyát, látótérbe hozva a hallócsontláncolatot. A stapest fixáltnak találtuk, így oldottuk az incudomalleolaris ízületet, a stapes szárát KTP-lézerrel átvágtuk, és a szuperstruktúrát eltávolítottuk. Ezt követően retroauricularis metszésből szabaddá tettük a mastoid planumot. Limitált mastoidectomiát végeztünk, és azonosítottuk a nervus facialis mastoidealis szakaszát. A posterior tympanotomia során a középfülbe jutottunk, ahol az incus hosszú szárának distalis részét reszekáltuk (3/A ábra). A mütét következő lépéseként kialakítottuk az implantátum és a fixálórendszer csontágyát, ezután a rögzítőrendszert és a múvi incust ideális pozícióba állítottuk (3/B és 3/C ábra), majd az implantátum és az aktuátor is a helyére került. Azért, hogy a mütét alatt minél rövidebb ideig legyen nyitva betegünk belső füle, ezen a ponton került sor a stapedotomia elvégzésére. A fixált stapestalpon először KTP-lézerrel rozettát képeztünk, majd mikrofúró segítségével átfúrtuk a talpat (stapedotomia). A stapedotomiás nyílásba $5 \mathrm{~mm}$-es NITIBOND (Heinz Kurz GmbH Medizintechnik, Dusslingen, Németország) pisztont helyeztünk, melyet az arteficialis incushoz csatlakoztattunk (3/D ábra). Az implantátum felett a kötőszövetet felszívódó, a bőrt intracutan öltésekkel egyesítettük, a hallójáratba pedig Merocel (Medtronic, Dublin, Írország) csőtampont tettünk. Betegünk mưtét utáni időszaka eseménytelenül zajlott, szövődményt nem észleltünk, és 4 napot követően otthonába bocsátottuk.

A több mint 3 évvel a mütétet követően, szabad hangtérben elvégzett audiológiai mérésen, az összes mért frekvencián $50 \mathrm{~dB}$ feletti, míg a beszédfrekvenciák területén $(500 \mathrm{~Hz}-4 \mathrm{Khz}) 60 \mathrm{~dB}$-t is meghaladó javulás volt kimutatható (2/B ábra). A beszédküszöb-vizsgálaton 40 dB-en $70 \%$-os eredmény volt mérhető, míg a beszédértés-vizsgálat $50 \mathrm{~dB}$-en 70\%-nak adódott.

\section{Megbeszélés}

A Codacs ${ }^{\mathrm{TM}}$ implantátum abban az esetben javasolt, ha súlyos fokú, siketséggel határos, kevert típusú, kétoldali hallácsökkenés áll fenn, és a csontvezetéses implantátumokkal már nem lehet megfelelő hallásrehabilitációt elérni [7]. Fontos, hogy ezen implantátum vibrációs akusztikus ingert alkalmaz - szemben a cochlearis implantátum tisztán elektromos ingerlésével -, tehát a residualis hallás a terápia sikerességének előfeltétele [8].
A mütéti technikát illetően több behelyezési metódus ismert. Häusler és mtsai mastoidectomiát követően széles posterior tympanotomiát készítettek, és ezen keresztül végezték el a stapedotomiát, majd a piszton behelyezését [9]. Bruschini és mtsai a stapedotomiát az ovális ablakra való jobb rálátás céljából a külső hallójárat felől, a dobhártya felemelésével végezték. Az általuk leírt technika során kisebb mastoidectomiára és csak kis anteriorsuperior tympanotomiára volt szükség, ami csökkentette a nervus facialis és a cochlea iatrogén sérülésének valószínûségét, továbbá közel a felére redukálta a mútéti időt (4 óra versus 2 óra) [10]. A stimuláció helyét illetően többféle lehetőség adódik, melyek közül a leggyakrabban a stapedotomiát követő pisztonbehelyezést alkalmazzák (1. ábra). Ha a mútét során mobilis stapestalpat látunk, akkor a kengyel fejecsére helyezett, harang alakú protézissel ugyancsak ingerületbe hozható a belső fül folyadéktere. Hasonlóan jó eredményekről számolnak be a kerek ablakba helyezett direkt akusztikus eszközök kapcsán [7]. Az egyik legnagyobb DACS-implantált beteganyaggal rendelkező klinika (Hannoveri Orvosi Egyetem) egy multicentrikus tanulmányban a funkcionális nyereséget - a posztoperatív 6. hónapban készült küszöbvizsgálat alapján - átlagosan 56 dB-nek írja le. Az általuk közölt eredmények azt mutatják, hogy betegeik beszédértése szignifikánsan javult, és elégedettebbek voltak a DACS-készülékkel elért hallással, mint az előtte használt, hagyományos hallásjavító készülékekkel [11].

A fent részletezett szúk indikációs terület és a nehéz mútéti technika miatt a fülészeti implantológiában ritkán alkalmazzuk a direkt akusztikus hallásjavító eszközöket, bár mint esetünk szemlélteti, és a hosszú követési idő mutatja, válogatott betegeknél kiváló eredményeket lehet elérni ezen implantátummal.

Anyagi támogatás: A közlemény megírása, illetve a kapcsolódó munka anyagi támogatásban nem részesült.

Szerzői munkamegosztás: U. J.: A cikk megírása. G. I.: A mütét elvégzése, szakmai lektorálás. B. G.: Betegellátás. K. M.: Ábraszerkesztés. B. P.: Szakmai véleményezés. A cikk végleges változatát mindegyik szerző elolvasta és jóváhagyta.

Érdekeltségek: A szerzőknek nincsenek érdekeltségeik.

\section{Irodalom}

[1] Karosi T, Sziklai I. Etiopathogenesis of otosclerosis. Eur Arch Otorhinolaryngol. 2010; 267: 1337-1349.

[2] Rudic M, Keogh I, Wagner R, et al. The pathophysiology of otosclerosis: Review of current research. Hear Res. 2015; 330: 51-56.

[3] Arnold W. Some remarks on the histopathology of otosclerosis. Adv Otorhinolaryngol. 2007; 65: 25-30.

[4] Harmat K, Thurén G, Simon L, et al. Comparative evaluation of vertigo in patients after stapedotomy and stapedectomy. [Posztoperatív vertigo vizsgálata stapedotomián és stapedectomián át- 
esett betegeknél.] Orv Hetil. 2017; 158: 1503-1511. [Hungarian]

[5] Grossöhmichen M, Salcher R, Kreipe HH, et al. The Codacs ${ }^{\mathrm{TM}}$ direct acoustic cochlear implant actuator: exploring alternative stimulation sites and their stimulation efficiency. PLOS ONE 2015; 10: $\mathrm{e} 0119601$.

[6] Németh A, Tóth T, Gerlinger I. Implantable hearing devices. [Implantálható hallókészülékek.] Fül-Orr-Gégegyógyászat 2018; 64: 138-146. [Hungarian]

[7] Rhodes RM, Tsai Do BS. Future of implantable auditory devices. Otolaryngol Clin North Am. 2019; 52: 363-378.

[8] Kludt E, Büchner A, Schwab B, et al. Indication of direct acoustical cochlea stimulation in comparison to cochlear implants. Hear Res. 2016; 340: 185-190.
[9] Häusler R, Stieger C, Bernhard H, et al. A novel implantable hearing system with direct acoustic cochlear stimulation. Audiol Neurootol. 2008; 13: 247-256.

[10] Bruschini L, Forli F, Vito A, et al. A new surgical approach for direct acoustic cochlear implant: a temporal bone study. Clin Exp Otorhinolaryngol. 2016; 9: 314-318.

[11] Busch S, Kruck S, Spickers D, et al. First clinical experiences with a direct acoustic cochlear stimulator in comparison to preoperative fitted conventional hearing aids. Otol Neurotol. 2013; 34: $1711-1718$.

(Uzsaly János dr., Pécs, Megyeri tér 3. I/5., 7623 e-mail: uzsaly24@gmail.com)

\section{"Iniuriam aures facilius quam oculi ferunt." (A jogtalanságot a fül jobban viseli, mint a szem.)}

A cikk a Creative Commons Attribution 4.0 International License (https://creativecommons.org/licenses/by/4.0/) feltételei szerint publikált Open Access közlemény, melynek szellemében a cikk bármilyen médiumban szabadon felhasználható, megosztható és újraközölhetö, feltéve, hogy az eredeti szerző és a közlés helye, illetve a CC License linkje és az esetlegesen végrehajtott módosítások feltüntetésre kerülnek. (SID_1) 